\title{
THE SENSE OF THE UNENDING IN JOYCE'S DUBLINERS
}

Vanja Vukićević Garić, University of Montenegro, vanja.v@t-com.me

10.31902/fll.25.2018.5 UDK 821.111.09Džojs Dž.

\begin{abstract}
Based on the main structural and narrative elements and drawing on the predominant views in the short story theory, this paper deals with the analysis of endings in Joyce's Dubliners, as well as with various modes of their constitution regarding the effect they produce. Since the ending is regarded as the crucial component of short fiction, and bearing in mind the exuberant formal, thematic, symbolic and poetic potential that Joyce's concept of epiphany has in the structuring of ends, it can be said that Dubliners is a collection that set the standard in the genre. This article aims at delineating the differences between the closed and open ends, pointing to the complex ontological implications of the latter ones, particularly in the light of the final story's ending, "The Dead", which also marked a multiple crossing of borders in terms of the form, genre and general poetics of James Joyce.
\end{abstract}

Keywords: ending, structure, closure, open end, epiphany, verbalization, liminal.

\section{The Introduction}

In addition to being generally regarded as Joyce's early and somewhat unusual masterpiece and, in many respects, the foundation of what will become his main aesthetic preoccupations in the later work, Dubliners (1914) is the collection which possesses all the qualities of the modern short story that have been identified as essential elements of this narrative form in the major attempts to define the genre. It has "[c]oncrete imagery, its way of focusing attention, of growing symbolic" (Lohafer 3); it is powerfully suggestive in its terseness, evocative rather than explicative, allusive rather then descriptive, and it often achieves the maximum effect with the minimum of devices. Moreover, some of the stories, such as "Ivy Day in a Committee Room", or "Grace", bear a strong structural resemblance to dramatic form, which is often included in the descriptions of important features of the short prose. Also, many of the characteristics that Baldeshwiler ${ }^{1}$, among others, lists as "poetic" elements of shorter prose narratives can be found in the majority of the stories, as Joyce

\footnotetext{
${ }^{1}$ See: Eileen Baldeshwiler, in Susan Lohafer, op.cit., pp. $18-20$.
} 
uses verbal devices remarkably to build up an atmosphere, tone and imagery in order to achieve density and intensity, so that his stories concentrate "upon increased awareness rather than upon a completed action" (Ibid. 20). It is the multilayered and intriguing connection between the completions, and the ends seen as (in)completions on the one hand, and the awareness they provoke on the other, that this essay will focus on, attempting to demonstrate how the structural shape of an ending creates a deeper sense of an unending story that transforms and extends the manifest meanings of the text.

Indeed, a "completed action" is difficult, if not impossible to find in Dubliners, even though the stories are considered exemplary in terms of realist-naturalist style. The plot, in a traditional sense of the word, is often absent and, on a surface level, it is hard to specify a theme, action or a set of motives in most of them, which has led a great number of readers and critics to define the stories as plotless. However, in spite of this (or, rather, because of this), there is always a sense that another narrative is running beneath the surface and that there exists a sort of double (dis)course: one manifest and one latent, the said and the unsaid part of the content. As this double line of development moves towards the story's end, the meanings become either clearer or even more baffling, since the expected climax of the closure sometimes turns into an anti-climax, containing all the complexity, ambiguity and luring radiance of an epiphanic moment. It is precisely owing to James Joyce that the word epiphany extended its primarily theological usage and became a literary term. It entered reference books as one of the central concepts around which Joyce constructed his art, as well as one of the crucial structural principles of the short story as a narrative form. The notion of epiphany has been largely exploited due to its abundant semantic, aesthetic and formal potential, since it is the vital constituent of an ending and ending is, as many writers and theoreticians of the genre asserted, the vital constituent of the short story. In this sense, Joyce in Dubliners set a standard which has been imitated throughout the decades. His epiphanies appear in various forms and with a different force; even though their intensity is not always the same, and neither is the extent of their implications, they nevertheless always provide the necessary degree of illumination and insight, achieving yet another, central and indispensable feature of the short fiction, the conditio sine qua non: the much talked about $a$ unity of the effect.

Some of the endings in Dubliners to be analyzed here come as a surprise, whereas the others appear as a predictable outcome of the previously presented - or usually only suggested - situation. Some of 
the closures point back to the text, clarifying its deliberately obscured places and thus forming a circular or spiral structural and thematic pattern. Some, on the other hand, offer a sense of silence, a sense that crucial information is still being withheld after the final word has been said. This silence, which is often permeated with a subtle irony, makes the end open despite its finality. The last story in the collection and one of the most analyzed stories in the entire history of the genre, "The Dead", ends in a cathartic and an apparently closed vision that unifies all the surface and undercurrent motives of both this story and the collection as a whole. However, being thus closed, it paradoxically conveys a powerful impulse of openness that, in its spiral return towards the leitmotifs previously developed or hinted at, completes and, in a way, transcends the entire structure. As this paper aims at showing, the ending of "The Dead" meant ending in multiple sense of the word, simultaneously suggesting a new beginning: an encounter with an indefinite and infinite region beyond the structural limits of the text it "closes".

\section{From Title to an End: a Double (Dis)course}

James Joyce wrote Dubliners in a traditionally realistic style, varying slightly the narrators' position of the neutral omniscience, inserting free indirect discourse occasionally, but maintaining an objective and ironic distance form the object of his narration. Accordingly, in most of the stories he applied the third person narrative voice, with the exception of the first three, those that belong to the childhood section ("The Sisters", "An Encounter" and "Araby"), which were written in the first person. Yet, even these stories, although reflected through consciousness or memory of a boy, reveal the author's choice of objective realism that often becomes naturalism with symbolic implications. Joyce's skill of selection and arrangement of details, location of brief descriptive passages, organization of particular information he chooses to present all disclose his ingenious economy of style. Of the four modes of prose fiction, ${ }^{2}$ he uses report and speech most frequently, making his narrative dynamic and free from obvious authorial intrusions. The comment is always imbedded and reduced to a subtle shading, visible only in tone, or an unobtrusive detail of an image. Thus, readers follow the story from title to an end through an apparently smooth, rational and logical tissue of signifiers. However, there is always a sense of another course of narration

\footnotetext{
${ }^{2}$ See: Helmut Bonheim, The Narrative Modes.
} 
running below or beyond the visible, an impression that a whole web of the unsaid is kept covered up, until it breaks through, or just sneaks through the surface of the said through a carefully chosen word or utterance, usually near the end of the story. David Lodge, quoting a phrase by Roland Barthes, observes:

"The stories look superficially as if they belong to the classic, readerly, realistic mode: [...]('the text is replete with multiple, discontinuous, accumulated meanings, and yet burnished, smoothed by the 'natural' movement of its sentence: it's an egg text') yet reader is likely to find himself forced continually to revise his sense of what any particular story is 'about' - uncertain therefore what revelation the story is moving towards, and apt to be taken by surprise when it finally comes." (Lodge 126)

The "surprise" of the ending and the silent perplexity that often stretches throughout the whole story is often caused by the choice of a title and the expectations it produces. Thus, the title of the story that opens the collection - "The Sisters" - is the "first stumbling block to the reader" (Ibid.), since the story is not about the sisters at all, but about their brother, the priest whose personality and death is enveloped by an upsetting veil of mystery, and about the boy who is the narrator. It is only through fragmented sentences and restrained, hidden information, that the reader begins to suspect that the priest is in the centre of the narrator's (and story's) attention:

"No, I wouldn't say he was exactly ... but there was something queer ... there was something uncanny about him. I'll tell you my opinion ...'

[...] 'I have my own theory about it,' he said. 'I think it was one of those ... peculiar cases ... But it's hard to say ...'” (Joyce, Dubliners 1 )

The trail of dots here conceals another, undercurrent development, another discourse which is intensified, prolonged and only partly revealed in the end of the story.

The second story in the collection, "An Encounter", leads readers' expectations at the beginning to a totally different direction from what will actually happen in the end: instead of encountering the "unkempt fierce and beautiful girls" (Joyce, Dubliners 9) from an American detective story, the boys on their adventurous trip meet just an old pervert who spoils the innocence of their childhood's fantasy. (It is significant that in the light of this story, the preceding one attains new connotations; paralyses and perversion - in more than one sense of both words - being the two predominant themes of the collection). 
Similarly, the title of "Two Gallants" contains all the sarcasm of Joyce's "scrupulous meanness" (Selected Letters 83), since it stands in a sharp contrast with the "gallantry" of the two protagonists. The baseness and futility of their lives is depicted by means of their dialogues, walking through Dublin being described with an exquisite topographical accuracy, yet all the sordid implications of their moral paralysis become fully evident in the end: the goal of their "gallant quest" is how to take out a golden coin from a poor working girl. Thus, the contrast between the nobility suggested in the title and the ignoble aspects of the reality presented in the story stands as a reminder of Joyce's constant play with the double signifieds of a seemingly simple signifier. The same goes for the story titled "Grace", in which ambiguity of the whole text acquires even more universal implications. The term grace here stands for God's mercy, as well as for a business transaction; it is a sinner's chance for redemption and salvation, as well as time to pay in the mundane, literal sense of giving money to someone. Ending the story with: "Well, I have looked into my accounts. I find this wrong and this wrong. But, with God's grace, I will rectify this and this. I will set right my accounts." (Joyce, Dubliners 126) Joyce reinforces the semiotic duplicity of the meaning that has run between the title and the closure.

Arguing that no definite set of theoretical rules can describe or be applied to the elusiveness of a successful short story, Guillermo Martinez, an acclaimed Argentine writer and mathematician, compares the process of writing a story with a performance of "an illusionist who distracts his audience's attention with one hand while performing his magic trick with the other". (Martinez) In his article "Short Story as a Logical System", he elaborates the thesis about the duality of logic that marks the course of a story, in which, as a matter of fact, two different courses (and discourses) run parallel from the beginning to an end that usually shockingly dissolves the duality. Summarizing one of the laws of short fiction stated by Ricardo Pilla, Martinez says that: "all short stories are the articulation of two stories, one superficial and the other subterranean, i.e. a secret the writer gradually divulges and which is only fully revealed at the end." (Ibid.) Rephrasing Pilla's idea in mathematical terms, he goes on to replacing the "two stories" with the "two orders of logic", which coexist as a tacit agreement between the author and the reader, the first being the common-sense and rational logical recognized as a realistic "normalcy" and the other being the fictional and the magical logic of the art. He explains their functioning in the following terms: 
"Whatever seems accidental in the initial logic is necessary in the logic of fiction. The writer needs those elements one way or another to arrive at a second order of which only he is aware at first. The second order is governed by another logic and the whole magic art - the short story writer's sleight of hand - consists in transmuting and substituting the initial logic of normalcy with the second fictional logic which gradually molds to the story and which, in the end, must be seen - if everything works as it should - as a fatality and not a surprise." (Martinez)

Although it is disputable whether Joyce discloses the secret fully in the end, which is the premise that both Pilla and Martinez implied, it is certain that over a century long history of critical reception has confirmed the general impression that something is withheld in most of the stories in Dubliners, kept down as an understatement during the entire course of the narration, despite its realistic mode. Thus, Martinez's idea of two parallel systems of logic in every short story that possesses an artistic value, which begin as one and united but are being doubled as the story progresses, seems very suitable tool for pinning down the sense of two simultaneous structures that Joyce creates. The choice of details, pieces of information given at the beginning, a particular word, phrase or image, is very important, as it is through these particulars that the understory, the "subterranean" composition, prevails and eventually replaces the surface-story. The awareness about this latent course of the story, which is in Joyce's texts usually articulated as a special discourse of silence, increases as the story progress, bringing an end which, as Martinez propounds, does not come as a surprise. The coexistence of two narrative lines imperceptibly and gradually makes us aware that the calm and often uneventful surface of the sketches of Dublin's life hides a whole web of disturbing developments, complex psychological relations and profound of human problems. Not one detail of these stories can be removed without doing harm to the whole, even though some pieces of information might seem unimportant at the first reading. Hence, we may wonder why the story about a spinster with a "normal", agreeably monotonous life is called "Clay", until we come to read about a game played on the Halloween and Maria's feeling of "a soft wet substance with her fingers" (Joyce, Dubliners 75), and all the sad and gloomy implications it brings. Near the end, all the pretence and emptiness of her life breaks through the ominous silence in the moment when she touches the clay, the sign of death in the fortune-telling game, instead of one of those marriage and fertility symbols. Similarly, in many other stories, what seems a casual 
description, turns into a powerful indicator of something much larger than the manifest narrative communicates.

Just as Joyce perceived the holes on the facade of a calm and contented life of Dubliners through which a dreary paralysis sent its dark hints, so can an attentive reader spot the crucial points in the pattern of the author's scrupulous style behind which he performs another narrative "trick". However, being more than a common "illusionist", to use Martinez's metaphor, James Joyce does it all with one hand. It is only in the epiphanic finality of the closure that we observe the totality of the effect and the unity of the two courses that have existed all along from its title to the end.

\section{Epiphanies: Completing and Transcending the Structure}

If the short story is "the most end-conscious of literary forms" (Lohafer 50), then we may agree that Joyce's short stories are the most epiphany-conscious examples of this literary genre. The term epiphany comes from Christian theology and denotes "a manifestation of God's presence in the world" (The Concise Oxford Dictionary of Literary Terms 84). James Joyce was the first writer to apply it to secular revelations everyday situations when, in a brief and passing moment, the essence of a thing, person, event or a phenomenon becomes evident - and introduce it as one of the principal aesthetic and structural devices of his fiction. His epiphanies sometimes function as symbolic exposing of the characters to a moment of self-awareness, and therefore remain within the story, as an element of a closed, full end. They represent the crucial turning points in both outward and the psychological action of the story, completing the pattern in which the content is represented with the force of an insight that is shared between the readers and the protagonists. There is also another kind of epiphany, the more frequent in Dubliners, which involves only observers (i.e. readers) and excludes the protagonist, who remain deprived of the transformative revelation and, therefore, unchanged. The light of this kind of insight is located outside the story and leaves its end open to various, often opposed interpretation. Consequently, this kind of closure contains a seed of anti-closure and, despite the precision of the image and the definiteness of the sentence that concludes the narrative, it stretches beyond the story. Eventually, many of the epiphanic endings in Dubliners clarify the uncertainties or hidden metaphors carefully scattered through the storyline, giving clues to some of the deliberately obscured or omitted information. As a result, the end casts a whole new light on both the manifest and latent structure of 
the story. Pointing back towards the unclear or unsaid places in the text, this kind of revelatory closure creates a spiral form which often supersedes the immediate meanings and adds new symbolic implications.

\section{1. The End as a Trail of Dots}

Explaining the foundation of his whole poetics - his conception of epiphany - James Joyce wrote:

"By an epiphany he meant a sudden spiritual manifestation, whether in the vulgarity of speech or of gesture or in a memorable phase of the mind itself. He believed that it was for the man of letters to record these epiphanies with extreme care, seeing that they themselves are the most evanescent of moments." (Joyce, Stephen Hero 188)

The passage shows that Joyce has himself divided his epiphanies into those which happen outside the beholder, i.e. the protagonist of a story, and those which occur within a character, "in a memorable phase of the mind itself". Consequently, in the first group described, when an object (or a state, a situation, an aspect of life) is epiphanised, and when "its soul, its whatness, leaps to us from the vestment of its appearance" (Ibid. 190), the radiance of that revelation may pass the characters of the narrative and be transferred somewhere outside the story, or be prolonged, suspended, unfinished. In those cases - and the majority of the stories in Dubliners end in that way - the protagonists remain in the darkness of their stagnation, unchanged by the touch of epiphanic vision and unable to see the true meaning of their situation. Thus, instead of the expected closure, we often find just a trail of information, a broken message, presenting a discontinued groping in the dark of unawareness. Revelation and knowledge are located beyond the text, extended towards the reader. The significance of "the vulgarity of speech or of gesture" that constructs the final scene is, therefore, displaced into another ontological level, above, or behind, the structure of the story. The end of the text contains only a trace of might have been a conclusion, usually presented in fragmented syntax or a simple sentence of understatement.

In "The Sisters", this trail of dots occurs literally at the end of story, making us "wonder whether we have been told the 'whole story' after all." (Lodge 127). The missing parts are strongly suggestive here, as if the utterance broke apart under the heaviness (or 
unpleasantness?) of the possible meaning, leaving it jagged, uncompleted, and evasive:

"Eliza resumed:

'Wide awake and laughing-like to himself... So then, of course, when they saw that, that made them think that there was something gone wrong with him...'." (Joyce, Dubliners 7)

The narrator, who is both a witness and an involved participant in the mystery, is held at a distance at this moment, which gives this final statement a quality of directness. Moreover, the fact that the words are twice repeated by one of the sisters illustrates a sort of paralytic compulsion to repeat the same closed circle of evasion, without finding a way towards a definite conclusion and revelation.

Susan Lohafer, one of the most prominent short story theoreticians, uses metaphors of gasp and sigh to describe two common types of ending and the effect they produce ("And so it can happen explosively, like the burst at the end of a deep inhalation. [...] Or it can happen gently, like the quiet end of a long exhalation" (Lohafer 97)), also emphasizing a special kind of closure (although the word anti-closure would be more adequate here), which is "caught between a gasp and a sigh" and that is: "holding its breath." (Ibid. 102). The fourth story in the collection, "Eveline", is certainly one of the stories which end in this way. Thematically, it is the central symbol of the Irish paralysis Joyce wanted to depict in Dubliners; formally, it is somewhat different from other stories, since the free indirect speech is the prevalent mode, used to achieve a proper balance between the realistic third person narrative voice (used here for the first time in the collection) and the depth of psychological penetration provided by this choice of discourse. The epiphanic vision in this story belongs entirely to the outside observer, whereas the heroine remains frozen in the emptiness of the moment, "with white face [to him], like a passive animal" (Joyce, Dubliners 26), unmoved, unaware, unchanged. Just as she is holding the iron railings firmly with her hands, so do we hold our breath in the absence of a final movement that would determine a denouement of the story of her consciousness.

In "After the Race", "Two Gallants" and "Counterparts", the epiphanic light is completely absent from the level of narrative discourse. The ending of all three stories is like "a long exhalation", a slow progress towards "the dark stupor" (Joyce, Dubliners 31) that will cover up and postpone a possibility of an insight. The end of "Counterparts" - certainly the most disturbing and relentlessly realistic in its representation of the sordid reality - produces a sense of 
stagnation, drawing the whole story deeper in the image of abuse and helplessness. The futility of Farrington's life escalates in domestic violence, and the only certainty that the final words of his molested son produce (they also end with a trail of dots) is that the situation is repeated and repeatable - until when...?

Maria from "Clay" is also incapable of a transformation, and Doran from "The Boarding House" has just a vague sense that "he was being had" (Joyce, Dubliners 46). This story, as well as "A Mother", ends with a subtle and ironic portrayal of human psychology, cunning plans and petty goals, understated and suppressed as always in Joyce. Again, the structure of the sentences is simple and short, the closure is swift and definite, expressing apparently neutral information in an even tone. And yet again the minimalist verbal devices suggest a plurality of meanings and connotations under and above the density of this style.

"Ivy Day in the Committee Room" seems the most suspended between a closed and an open ending. On the surface level, everything seems clear here: dramatically constructed scenes, dynamic exchange of political opinions, drinking, informal colloquial speech, many local expressions. However, the silence in the end oddly destabilizes the short, plain dialogues.

"'What do you think of that, Crofton?' cried Mr Henchy. 'Isn't that fine? What?'

Mr Crofton said that it was a very fine piece of writing." (Joyce, Dubliners 98)

The reader may just wonder, when the story is finished, how many undertones - subversive, ironic, politically and historically contextualized but psychologically universal - this "closed" and uncolored ending contains?

\section{2. A "Genuine Pause"3}

As it has already been mentioned, some of the stories in Dubliners contain an epiphanic closure within the text, on the same ontological level as that which is occupied by the characters, events, and other discursive elements of the fiction. "The Dead" is doubtlessly the masterful example of these, but there are also others in which the protagonists share the illuminating insight offered to the readers and

\footnotetext{
${ }^{3}$ David Daiches, The Novel and The Modern World, The University of Chicago Press, Chicago and London, 1960, p.70.
} 
are, at least for a brief moment, touched by a knowledge, or selfknowledge, which completes and, to an extent, transforms the previously described state. The moment of this kind of a closure, as Daiches observed, corresponds to something in human experience: this pause is genuine, real, and the end concludes the preceding pattern in a natural and coherent manner.

"The beginning is vague [...], but once under way the jagged line becomes straight, until the end, which is precise and definite.

[...]

A series of events is recognized as having constituted a totality, a 'significant experience', in virtue of its close, not of its opening." (Daiches 69)

This particularly refers to the stories told in the first person, where "a genuine climax of realization" (Ibid.) closes a process of mind or a memory in a lucid articulation of the highpoint of awareness. Thus, the boy from "An Encounter" learns something about the adult world and himself from the experience of the trip. And the final passage is again rapid and succinct in its mimetic realism, the sentence again dense and syntaxically undemanding. The depth of realization is even more swift and subtle in Araby, a story pervaded by a poetic symbolism and written in a far more lyrical style than the others (with the exception of the last pages of "The Dead"):

"Gazing up into the darkness I saw myself as a creature driven and derided by vanity; and my eyes burned with anguish and anger." (Joyce, Dubliners 21)

This final phrase (and "phase of mind") relies on every word to reveal the fullness of its implication; even the sound properties (alliteration, rhythm) contribute to the unity and significance of the effect.

Even though the physical closure in Joyce's stories is almost always precise and automatic, the sense of silence established at the end follows organically out of the previously presented and carefully organized patterns and is often produced by fully planned, successive stages in the text. Therefore, the gap between the physical and cognitive conclusion, ${ }^{4}$ which is always, at least slightly, deferred in Joyce's art, is reduced by the genuine development of the whole texture. In the story with a symbolical rather than realistic title - "A

\footnotetext{
${ }^{4}$ See: Lohafer, op.cit., p. 43.
} 
Little Cloud" - we find several turning points, shifts of mood and tone, before we eventually reach the final stage in which the protagonist attains a self-knowledge through repentance. Thus, we notice that the process of ending here begins somewhat before the actual physical end, in the moment of Little Chandler's realization that "Gallaher was only patronising him by his friendliness just as he was patronising Ireland by his visit" (Joyce, Dubliners 56). Here starts the process that will lead to a climax of his changing moods: melancholy, hope, excitement, envy, frustration, rage, disillusionment - and the culminating sense of imprisonment that is, logically and predictably, intensified by guilt caused by the neglect of the baby:

"Little Chandler felt his cheeks suffused with shame and he stood back out of the lamplight. He listened while the paroxysm of the child's sobbing grew less and less; and tears of remorse started to his eyes." (Ibid. 59)

With the "tears of remorse", Little Chandler transcends his immediate frustration and furious resentment against the fate and the friend who "had got on" (Ibid. 49) and becomes aware of a life outside himself, aware of his responsibility towards the child. It is all psychologically realistic, corresponding to interior human experience. Yet, Joyce makes not only thematic, but also a stylistic shift here - a pull beyond the expected. After going through a series of broken sentences and repetitions which intensify the represented feelings, the narrative voice reassumes its fluidity and almost lyrical smoothness, which textually embody a gesture towards a possibility of redeeming awareness.

Similarly, Mr James Duffy from "A Painful Case" experiences two opposite states of mind before he finally touches the redemptive light of an epiphany. At the news that Mrs Sinico is dead, his first feeling is that of a revulsion, a cruel intellectual coldness and snobbery, and only after that is he moved to feel compassion and regret. However, this story has not a double, but a triple frame of ending, for after the brief moment of sympathy and insight, Mr Duffy returns to emotional silence, just as the train he listens to disappears in the night and just as the story reduces its descriptive abundance with the sentences that become shorter and shorter, until they come to an inevitable pause:

"He turned back the way he had come, the rhythm of the engine pounding in his ears. He began to doubt the reality of what memory told him. He halted under a tree and allowed the rhythm to die away. He could not feel her near him in the darkness nor her voice 
touch his ear. He waited for some minutes listening. He could hear nothing: the night was perfectly silent. He listened again: perfectly silent. He felt that he was alone." (Joyce, Dubliners 84)

\section{3. Pointing Back Towards and Beyond the Story}

"Where - and when - do we begin to have a story?" (Lohafer 52 ) is one of the frequent questions asked by the still new and growing theory of short fiction, especially in reader-response oriented one. A general impression after reading a story in Dubliners is that we "have it" only in the end, although we start to sense it in certain places in the pattern, "between two sentences" (Ibid.), under a dense detail, between silence of the dots or beyond a deliberate gap left in the text. However, it is usually in the more or less epiphanic end that the story comes into being, since the closure, no matter how closed it really is, frequently casts a whole new light on the preceding elements of structure, filling the elided places with new meanings and suggestions. One of the main features of Joyce's technique in Dubliners was to leave some of the themes obscured, formally incomplete and unexplained, surrounded by a veil of mystery and unintelligibility. He also created intentional gaps, elisions, slits on the surface level of the stories, depriving the reader of the information that would turn out to be crucial for the understanding of the final effect.

Only on a second reading, after we found out what happened in the end, are we capable to grasp why Joyce used a certain description where he used it, why he made this or that choice of the word, why he arranged and located particular details of report or a dialogue in the way he did. For instance, when we finish reading the last lines of "The Sisters", we immediately remember the disconnected and evasive utterance of old Cotter and the impression they made on the boy who struggled, along with the readers, "to extract meaning from his unfinished sentences" (Joyce, Dubliners 2). The final disclosure in "An Encounter" directly relates to the puzzling scene earlier in the story when the old pervert "shivered once or twice" (Joyce, Dubliners 13) while speaking about young boys and girls, and a vaguely disquieting impression that made on the narrator. Also, the end of "Eveline", with its powerful representation of the heroine's paralytic inability to act, to change and improve her life, points back towards the memory of her mother whose life closed in "final craziness" (Joyce, Dubliners 25), within a paralytic circle of repetition of one "foolish sentence" (Ibid.). After the closure of "After the Race", we can better understand why Jimmy "was too excited to be genuinely happy" 
(Joyce, Dubliners 27). In the same way, the fact that Mrs Mooney from "The Boarding House" is called "The Madam" (Joyce, Dubliners 43) becomes significant only in the end, when the term assumes strongly ironic and derogatory connotations. Therefore, what seems a casual detail at the beginning or in the middle of the story, an offhand information with no particular importance, turns into a potent symbol and a most meaningful element in the end of the text.

Joyce's endings thus point back towards the gaps and elisions left in the narrative in order to clarify them and fill them with new implications. This forms a sort of circular structure, which completes and possibly re-arranges the existing design of the text. Furthermore, since the intriguing details which in Dubliners always become more conspicuous and understandable when we reach the end tend to "lead us out of the text", (Hanson 23), giving an open quality to the short story, we can say that this circular movement from the end back to the preceding text also pushes forward the boundaries of the story's structure. The sense of openness results from the short fiction's capacity to stimulate reader's imagination in a particular way, and to create multiple meanings in the plurality of responses. As Clare Hanson points out, short story is often structured as a dream - it bears a strong affinity to the unconscious (pp.22-23). Even though Joyce's stories in Dubliners are realistically presented, with the surface organization that communicates easily with the rational, common-sense level of reception, they still "allow images from the unconscious mind [..]to present themselves in the text in a relatively untranslated state" (Ibid. 25) and hence to stir in the reader, my means of the elliptical constructions and undefined places, "that image-making faculty which would otherwise lie dormant" (Ibid.). A possibility of translating those images in the act of interpretation rises only from the end of the story, which then, spirally, adds new meanings to be translated, leading not only backwards, but also somewhere outside and beyond the text itself.

\section{Instead of the Conclusion: "The Dead" - A Glimpse of Something Else}

The last story of Dubliners stands apart from the rest of the collection, both structurally and thematically, differing from the other stories in its style, its length, its both surface and undercurrent content and configuration and, most certainly, in its ending. The final epiphany of "The Dead" invokes a much larger frame of reference than any other revelation of any other story. Furthermore, it does not only close the 
pattern of the whole book in the structural sense, but also recapitulates, repeats and builds on many motives, symbols and images from the previous stories. Spirally pointing to the preceding parts of the collection, it completes the insight into the life of Dublin, Ireland and the whole humanity, at the same time transforming the picture of physical, psychological, social and cultural realities depicted with such an outstanding topographical accuracy and precision. The expanding vision with which "The Dead" ends, as well as the lyricism and symbolic profusion of Joyce's style in it delineated a sort of boundary in the author's creative development, after which he turned to entirely different literary forms and techniques, never to return to the short fiction genre again. This story, therefore, marks the end in yet another sense of the word: a masterful finale of an aesthetic and spiritual phase of one of the most notable twentieth century authors.

According to David Daiches, "The Dead" is the only story in Dubliners with a fully articulated and "preconceived theme" (74), which is systematically worked out, selected and arranged. That theme can be described as "the assault on the walled circle of Gabriel's egotism" (Ibid. 75) and the result of that assault, which is: sympathy, understanding and melting of identity in the epiphanic, visionary communion with the living as well the dead. After attending a jovial annual party, full of trivial details and sentimentalities, hosted by his aunts, and after succeeding to make a good impression on everyone, which was very important for him, Gabriel Conroy, all of a sudden, sees his wife "standing on the stairs in the shadow, listening to distant music" (Joyce, Dubliners 151). What strikes his perception in that moment is an unexpected and strange vision of "a grace and mystery in her attitude as if she were a symbol of something" (Ibid.). From that moment on, he becomes driven with a passionate desire for her, impatient to revive all the intensity of their love and romance dulled by the monotony of marriage. However, his perception changes radically when he discovers that he is not the reason of her "mysterious grace" and that all along she has been thinking of her girlish love - a boy who had died loving her long time ago. Becoming aware of the existence of another world in his wife's memory, of the world that exists independently of his own, Gabriel feels that his elevation, his desire, his self-confidence and the flattering image of himself are shattered:

"He saw himself as a ludicrous figure, acting as a pennyboy for his aunts, a nervous, well-meaning sentimentalists, orating to vulgarians and idealising his own clownish lusts, the pitiable fatuous fellow he had caught a glimpse of in the mirror." (Ibid. 158) 
With all the other stories in Dubliners, the narrative would have probably ended here, if not even earlier: in the image of Gretta's motionless listening to a distant music and the hints of mystery suggested by it. But Joyce's intention here was to take the protagonist (and the story) a step further, beyond the glimpse of himself as a disillusioned, "ludicrous figure". The epiphanic revelation of this story is deeper and larger than that, it offers a glimpse of something else universal and timeless - and all the elements of the design, theme and style are surrendered to that final vision. The process towards a selfknowledge is continued in Gabriel's mind and leads him towards a unique cancellation of the self in a generous identification with the others: his wife, the deceased Michael Furey, and all the humanity. The transcendental quality of the experience is realised through an intensely poetic and fluid style, nothing like the "scrupulous meanness" of the preceding stories:

"His soul had approached that region where dwell the vast hosts of the dead. [...] His own identity was fading out into a grey impalpable world: the solid world itself which these dead had one time reared and lived in, was dissolving and dwindling.

[...] His soul swooned slowly as he heard the snow falling faintly through the universe and faintly falling, like the descent of their last end, upon all the living and the dead." (Ibid. 160)

"The Dead" is the only story that does not end with "another frustration, another stoppage" (Davies xvii), the only story whose protagonist grows and develops, the only story that in the radiantly enlarging ultimate epiphany encompasses all the previous discoveries and revelations, all renunciations and broken phrases, all the silence, lacks and possibilities. It provides, in one sense, a closure of closures, since it offers a traditional, cathartic bringing-to-an-end vision, a synthesis which resolves and transforms the previous lines of both this story and the entire collection. However, in another sense, strongly connected to the formal and symbolic idiosyncrasy of its language the language whose semantic abundance and sonority blurs the line between poetry and prose, the narrative mode at the end of "The Dead" questions the very possibility of a closure. Since the narrative voices and perspectives begin to multiply and merge as the story approaches its ending, it becomes increasingly difficult to locate the origin of the discourse(s). ${ }^{5}$ Furthermore, as the natural consequence of

${ }^{5}$ For the narratological analyses and the ontological implications of the narratively polyvalent nature of Gabriel's vision see Riquelme's masterful study Teller and Tale in Joyce's Fiction: Oscillating Perspectives. 
the narrative and ontological uncertainty of the last passages, the nature of Gabriel's experience and its verbal articulation become increasingly more ungraspable by the ordinary logic and ordinary language structures, oscillating, in fact, between the speakable and the unspeakable ${ }^{6}$, and also transgressing the limits of the genre. It is the very grandness of this vision that, with its synthetic and revelatory clearance as well as its liminality, carries an energy of anti-closure and a sense of open, unlimited quality.

At last, it seems appropriate to remind that writing of "The Dead" did not "close" only a short story collection. For James Joyce, it meant closing a phase of artistic development and a phase of life, after which he turned to revising Stephen Hero into A Portrait of the Artist as a Young Man (1916), making plans for Ulysses (1922) and Finnegans Wake (1939) - the novels which pushed the limits of literary presentation to the point of revolutionizing the relationship between language and human experience, also deconstructing the concept of endings. Dubliners is, therefore, a book which ends with a beginning: its author's acknowledgment of the unending possibilities of the new modes of expression.

\section{References:}

Bonheim, Helmut. The Narrative Modes. New Hampshire: D.S. Brewer, 1982. Brooker, Peter, Ed. Modernism/Postmodernism. London: Longman, 1992.

Daiches, David. The Novel and the Modern World. Chicago and London: The U. of Chicago P., 1960.

Davies, Laurence. "Introduction". James Joyce, Dubliners. Hertfordshire: Wordsworth Classics, 1993.

Ellmann, Richard. James Joyce. New York: Oxford University Press. 1982.

\footnotetext{
${ }^{6}$ Riquelme makes an important observation regarding the nature and the limits of Gabriel's vision, as well as about the limits and (im)possibility of the narrative language to present the unpresentable, since "that region where dwell the vast hosts of the dead" is by definition unspeakable, the place where the language known to the living also stops. Hence, no familiar narrative style can serve as an adequate verbalization of Gabriel's thoughts and internal experience. Cf. John Paul Riquelme, "For Whom the Snow Taps: Style and Repetition in 'The Dead'”, in: Daniel R. Schwarz, ed., James Joyce, "The Dead" p. 223.

7 For the importance of biographical background for "The Dead", see Ellman's James Joyce. pp. 243-253.
} 
Hanson, Clare, Ed. Re-reading the Short Story. New York: St. Martin's P., 1989.

Joyce, James. Dubliners. Hertfordshire: Wordsworth Classics, 1993.

Joyce, James. Stephen Hero. London: Panther, 1984.

Lodge, David. The Modes of Modern Writing. London: Edward Arnold, 1983.

Lohafer, Susan. Coming to Terms with the Short Story. Louisiana State University Press, 1983.

Martinez, Guillermo, "Short Story as a Logical System". Translation by Susan Ouriou. Published in Descant 112 (Canada), 2001. http://guillermomartinezweb.blogspot.com/2011/06/short-

story-as-logical-system.html, accessed at: November $5^{\text {th }} 2018$.

McHale, Brian. Postmodernist Fiction. London: Routledge, 1987.

Riquelme, John Paul. Teller and Tale in Joyce's Fiction: Oscillating Perspectives. Baltimore and London: The John Hopkins University Press, 1983.

Schwarz, Daniel R. Ed. James Joyce, "The Dead" - Case Studies in Contemporary Criticism. Boston: Bedford - St. Martin's P., 1994.

Selected Letters of James Joyce. Ed. Richard Ellmann. London: Faber \& Faber, 1975.

The Concise Oxford Dictionary of Literary Terms. Ed. Chris Baldick. New York: Oxford UP, 2004.

\section{NAZNAKA OTVORENOG KRAJA}

Polazeći od osnovnih strukturnih i narativnih elemenata i oslanjajući se na dominantne stavove u teoriji kratke priče, ovaj rad se bavi analizom zavšetaka Džojsovih priča u Dablincima, kao i različitim načinima njihovog konstituisanja u odnosu na efekat koji ostvaruju. Budući da se kraj smatra najvažnijom komponentom kratke prozne forme, a s obzirom na formalni, tematski i simboličko-poetski potencijal Džojsovog koncepta epifanije u strukturiranju krajeva, može se reći da je zbirka Dablinci postavila standard koji i danas čini osnovu uspješnosti ovog žanra. U radu se ukazuje na razlike između zatvorenih i otvorenih krajeva u zbirci, kao i na složene ontološke implikacije ovih drugih, naročito u svjetlosti završetka posljednje priče, "Mrtvi“, koja je za Džojsa označila prelazak žanrovskih i poetskih granica u višestrukom smislu riječi.

Ključne riječi: završetak, struktura, zatvoreni kraj, otvoreni kraj, epifanija, verbalizacija, granično. 